\title{
The Global Securitized Subprime Market Crisis
}

\author{
Phillip Anthony O’Hara \\ Global Political Economy Research Unit, Curtin Business School, Curtin \\ University, GPO Box U1987, Perth, Australia. 6845. philohara1@yahoo.com
}

[Version 18b] [18 March 2009][Very Final Proof for RRPE]

\begin{abstract}
*
This paper examines the global securitised subprime crisis through the lens of core general principles of political economy. The principle of historical specificity is used to situate the crisis in cycles and historical time. The principle of circular and cumulative causation scrutinises the role of multiple factors and how they cumulatively impact on the system. The principle of contradiction explores the relationship between finance and industry through deregulation and changing industrial leadership at the global level. The principles of financial innovation and heterogeneous agents link to the intricacies of the different roles of economic agents in the circuit of mortgages and securitisation. And finally the principle of risk and uncertainty examines the contradictory role of complex institutions and calculative models of risk in the generation of high systemic uncertainty during booms in the cycle.
\end{abstract}

J EI Classification: B50, D02, D81, G01, P16,

Keywords: subprime market crisis; global impact; political economy; principles

\section{Introduction}

The purpose of this paper is to scrutinise the salient causes, nature of and likely consequences of the global securitized subprime market crisis (GSSMC). Special reference is given to explaining the most critical global financial and economic crisis since the Great Depression through the lens of the principles of (heterodox) political economy. The principles of historical specificity, circular and cumulative causation, financial innovation and heterogeneous agents, contradiction, plus risk and uncertainty are utilised to examine the nature of the crisis. Based on O'Hara (2007a,b, 2008a,b, 2009) these principles are used to explain the historical genesis of the crisis, the interaction of multiple factors and variables, the role of financial innovation and different economic agents in the development of chains of bankruptcy, plus the importance of an uncertain environment and complexity problems.

\footnotetext{
* An earlier version of this paper was presented at the annual meetings of the Union for Radical Political Economics at the ASSA meetings, San Francisco, 2-5 January 2009. I wish to thank the comments of participants and the role of Bill Dugger as chair of the session. This paper is dedicated to my mother, Rhoda Adelaide O'Hara (1915-2008), artist, dancer, writer, gardener, character and wonderful woman, who died while I was researching this paper. She was my best friend and confidant.
} 


\section{Principle of Historical Specificity and Cycles}

The first general principle of political economy is the principle of historical specificity, that an understanding of society should be embedded in history. What is the historical environment in which the GSSMC emerged? How does history help us to comprehend the problem? This is closely related to the principle of path dependence: things that emerge historically often become locked in and difficult to change. This relates to business cycles, long waves and institutional change. Cycles and waves are embedded in the dynamics of the history of US and other economies. For instance, the historical operation of cycles and long waves impact on financial/housing crises. Since the mid-1970s, the US economy (Wolfson 1996) and the global economy (O’Hara 2006) have been undergoing long wave downswing and serious periodic financial crises. The financial crises tend to occur variously before or during recessions; but they are closely linked to wave and cycle downswings as cause and/ or effect.

Since the 1970s the following crises, financial and economic, have been especially notable in the US and global economies, as shown in Table 1:

Table 1. US, Global Economic and Financial Crises, 1970s-2000s

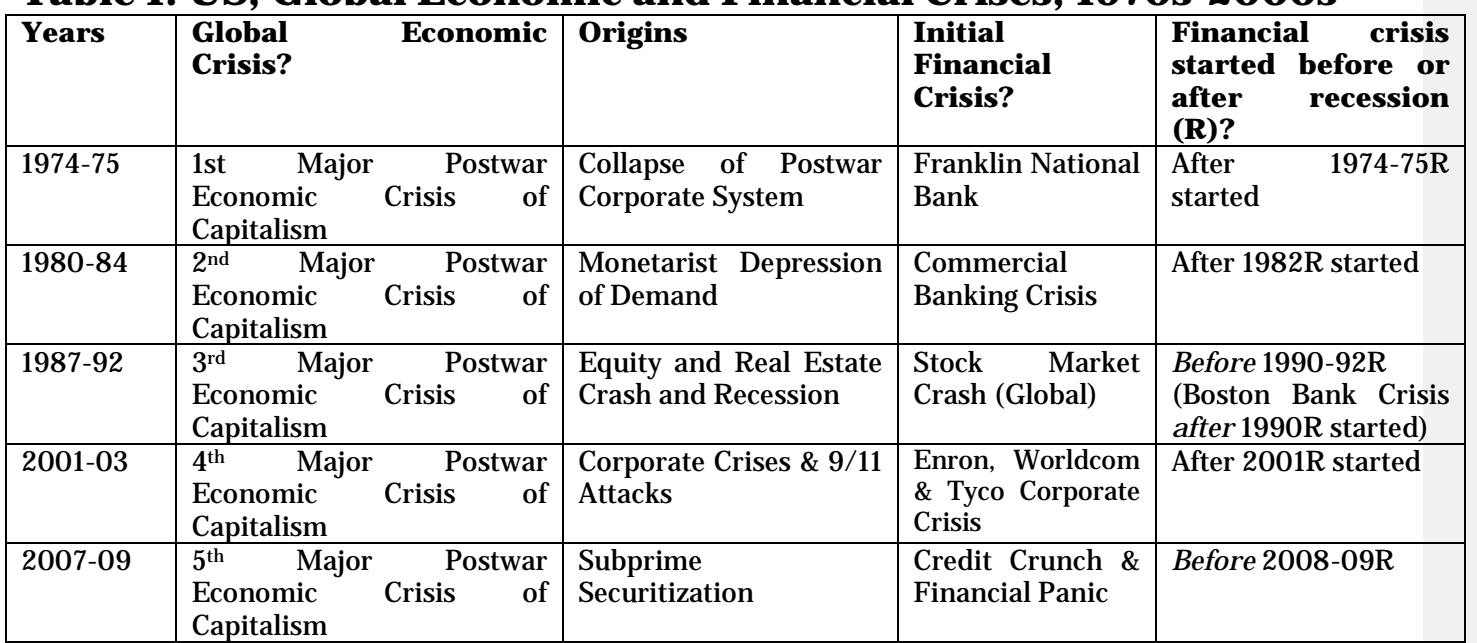

Source: Adapted largely from O’Hara (2006), Wolfson (1996)

The current crisis is thus not simply a financial crisis, but an economic crisis, and more generally a socioeconomic crisis of legitimacy for deregulated capitalism. It is a socioeconomic crisis because it is affecting finance, economics and society as a whole. It is linked to historical trends of corporate power, dampening real wages, and rising debt. It is part of the trajectory of successive financial crises and recessions over the past several decades (see Wolff 2009). But it is also a financial and economic crisis in a narrower sense. The usual pattern is recession followed by financial/corporate crisis; which occurred during 1974, 1980, 1982, and 2001-03. However, sometimes booms in the short cycle have generated financial crises before recession. This was the case with the stock market crash of 1987 and the GSSMC of 2007-09. These latter financial crises are a slightly different variety from those happening after the recessions have begun. The 1980s upswing set the scene for a whole series of financial escalations, such as leverage buyouts, share repurchases and corporate takeovers, often financed by credit. Low debt firms often became high debt firms very quickly, which stimulated a speculative bubble (globally and 
in the US), which crashed in 1987. However, a recession did not emerge in many nations until 1990, as a real estate boom manifested itself in many nations (after the equity crash) before expectations declined bringing on a recession.

Similarly, a weak upswing emerged in the US after the recession of 2001, while the corporate crisis continued through 2002 and 2003, so durable recovery did not eventuate until 2004 onwards. The associated corporate crisis, linked to Enron, WorldCom, Global Crossing, Arthur Anderson and a host of other companies, continued in the courts even until the recently. As recovery and boom established itself, various financial innovations and institutional changes led to the emergence of a subprime mortgage market expansion. This was stimulated by the so-called "low-risk" environment established by the boom. Major stakeholders such as the government, banks, risk-assessment agencies and others played a role. This is the environment in which the GSSMC needs to be situated.

The key difference between 1987 and 2007/09 is that the stock market crash in 1987 was generally followed by boom in another market (eg, property), and the fairly deep recession didn't emerge until the subsequent market decline around 1990-2. 2007/09 is different since a credit crunch occurred first (late 2007), then financial panic (late 2008) and recession (late 2008 and 2009). A decline in several market has been ongoing, including equities, housing, subprime/ collateralised debt, and resources. The economic crisis has become international in nature, and many are claiming it as likely to be the biggest crisis and recession for many nations since the Great Depression, as indicated by Table 2 below:

Table 2. Global Equity Crashes and Recessions, 2007-2009

\begin{tabular}{|l|l|l|l|l|l|}
\hline Country & $\begin{array}{l}\text { Variable 1 } \\
\text { (Equity } \\
\text { Market Index) }\end{array}$ & $\begin{array}{l}\text { Index } \\
\text { (Oct 2007) }\end{array}$ & $\begin{array}{l}\text { Index 2 } \\
\text { (Oct 2008) }\end{array}$ & $\begin{array}{l}\text { 12-Month } \\
\text { Impact } \\
\text { (Oct 2007 } \rightarrow \\
\text { Oct 2008) }\end{array}$ & $\begin{array}{l}\text { 2009 } \\
\text { GDP } \\
\text { Estimate }\end{array}$ \\
\hline ** \\
Iceland*
\end{tabular}

Source: Adapted from Yahoo Finance; Wikipedia (2009)*; RGE Monitor (2009) **; IMF (2008) \#

The Icelandic economy was virtually destroyed, since it was based mainly around the financial system (since deregulation), with the equity market crashing 92\% and real GDP likely to decline by around $10 \%$ in 2009, indicating a depression. Most of the major stock exchanges around the world crashed in the order of 40-60 percent over the 12 months to late October 2008. New York, London, Tokyo, Hong Kong and Sydney exchanges were severely impacted by the securitised subprime dislocation. Subprime and related financial linkages are increasingly affecting the real economy of production, employment and income, as the figures for the prognoses in 2009 imply. Sharp recession is expected in the US, UK, Japan (as indicated above) plus the world economy ( $-0.5 \%$ real GDP), Europe 
$(-2.5 \%)$, and Canada ( -1.5 to -2.0$)$, with much of the rest of the world experiencing positive but much lower growth (RGE Monitor 2009). In this light, governments around the world have been variously responding with rescue packages associated with lender of last resort facilities, nationalisation of financial enterprises, fiscal and monetary incentives, and even some bailing out of manufacturing firms.

\section{Principle of Circular and Cumulative Causation}

To comprehend the dynamics of the subprime mortgage market crises, and related phenomena, one needs to take a holistic perspective. A number of interacting factors are at work, and it cannot be reduced to a single factor approach (as Mian et al 2008 attempt). For instance, many authors recognise this interaction between many variables in a multicausal model (see Wray 2007). Gunnar Myrdal and Nicholas Kaldor call this multi-factor approach a model of circular and cumulative causation (CCC), since the variables are multiple and the magnified multiplier of all factors is often very sharp and unstable (a similar approach is developed by Stephen Resnick and Richard Wolff; see O'Hara 2000). The major CCC factors involved in this GSSMC are shown below in Figure 1:

Figure 1: Process of Circular and Cumulative Causation (CCC)

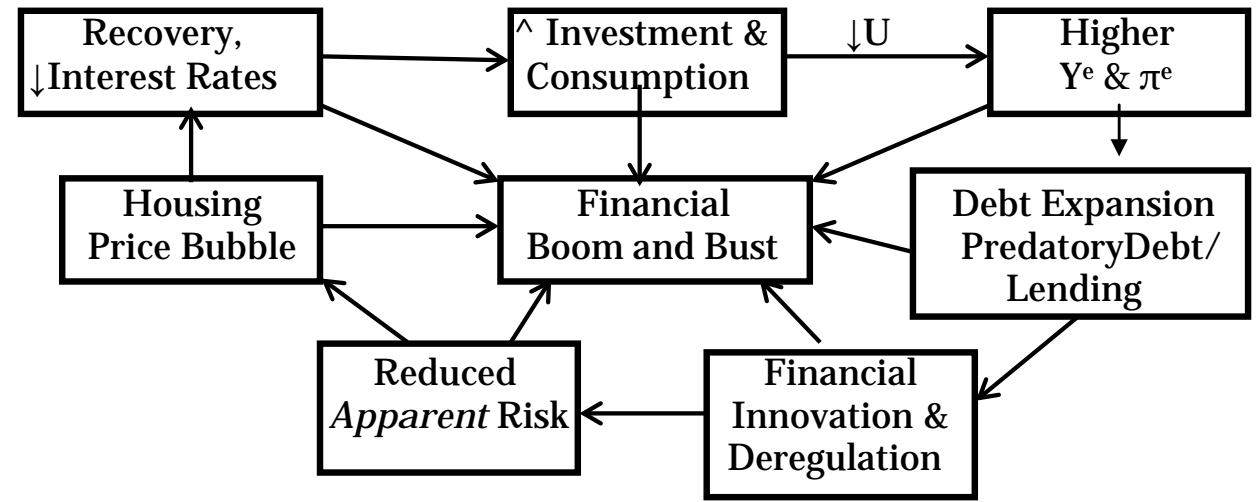

The initial recovery of aggregate demand from the early 2000s recession, lower official interest rates and less uncertainty eventually stimulated investment and consumption spending. This led to a period of optimism, lower unemployment, eventually expanding the share market, expected income (Ye) and profits $\left(\pi^{\mathrm{e}}\right)$ over 2004-2006. For instance, in the US the 8 month recession of March to November 2001 was followed by six years of (slow) recovery and then boom. Many nations of the world followed a similar pattern.

During business cycle upswing, credit overexpanded dangerously in relation to income, because euphoric conditions enhanced expected corporate income and profitability much greater than long-term corporate income grouth. Real wages have also been dampened while consumption has been rising financed by debt. This higher level of debt, including the democratisation of debt and predatory lending/ debt, contributed to the boom and fragility. In an environment of uncertainty, where prospective yield is associated with long-term conditions, the prevailing business climate is often used as a proxy for future conditions. Hence during apparently "good times" this leads to expanded credit as investment and consumption spending improve. During the recent era of neoliberalism finance has become more deregulated which has expanded credit access. This has been a global phenomenon. For instance, debt to income ratios have increased considerably over 
the past fifteen years, especially in advanced capitalist economies, as shown below in Table 3.

Table 3. Liabilities as a Percent of Disposable Income, Advanced Capitalist Nations, 1996, 2001, 2006

\begin{tabular}{|l|l|l|l|l|l|}
\hline & 1996 & 2001 & 2006 & $\begin{array}{l}\% \uparrow \\
1996-01\end{array}$ & $\begin{array}{l}\% \uparrow \\
2001-06\end{array}$ \\
\hline USA & 92 & 106 & 140 & 15.22 & 32.08 \\
\hline UK & 105 & 118 & 168 & 12.38 & 42.37 \\
\hline Canada & 107 & 114 & 128 & 6.54 & 12.28 \\
\hline EU & n.a. & 73 & 81 & n.a. & 10.95 \\
\hline
\end{tabular}

Source: Adapted from Mizen (2008:535)

Debt escalation was especially notable in the major neoliberal economies, such as the US and UK. The expansion of credit went hand-in-hand with the decline in quality of loans, as the boom led to bubbles in the major markets of housing and equities, as much of the housing and equity boom was financed through different forms of credit arrangements.

This is linked to the expected income-credit-investment transmission mechanism of boom and then crash through financial crises. First, a decline in uncertainty through optimistic business climate generates greater investment and consumption. This expansion of euphoria, credit and investment beyond fundamentals occurs to a much greater extent when there is wholesale deregulation of the financial sector. Hyman Minsky's distant memory hypothesis is relevant here, since agents tend to forget about past recessions and financial crises and set up their expectations based on the prevailing business climate. Also, much of the so-called investment is misallocated during eras of wholesale financial deregulation as the public good of stability declines. It is especially misallocated to the relatively cyclical and speculative sectors such as the secondary stock market, the property market and the foreign exchange market.

Financial innovation and deregulation, including disintermediation and securitisation of mortgage market securities, enhanced the boom and fragility. The financial innovation of securitizing subprime mortgages led to problems of lack of available market information about who had the mortgages, what was the quality of the collateral, and what would happen if the boom in housing and equity markets faltered. The complexity of the securitised mortgage bond was an especially critical problem leading to informational anomalies in the bond system.

Rating agencies and institutional mis-pricing of risk played a role. There has been a conflict of interest between ratings agencies, such as Moody's and Standard and Poor's, providing ratings for companies and also providing financial advice. The lack of suitable information exchange between borrower and broker, broker and originator, issuer and originator, trustee and issuer, asset fund and trustee, plus investors and asset manager, followed through to credit rating agencies. Appropriate ratings depend mainly on the quality and quantity of information, and rating agencies and others failed to incorporate appropriate risk into their calculative models. However, these ratings agencies also provided financial advice on how the buyer of the risk assessment might organise its bond offerings, which depends in part on the risk assessment provided. They were thus unlikely to criticise their own risk assessment in advising how to offer the bonds. The risk models also were highly contingent on rising housing prices, for instance, so that if alternative risk 
assessment scenarios (and other aspects of "stress testing") had been the norm this would have helped a great deal.

These multiple factors generated the housing, securitised bond and equity booms, which in turn enhanced aggregate demand while circular and cumulative causation ran through several runs over the business cycle. All of the factors contributed to the bubble and hence fragility and subprime crisis. Debt overexpanded based on euphoric expectations and bubbles in the housing and equity markets. The government played a critical role in reducing interest rates to historic lows, and then increasing them relatively rapidly. All this happened while agents assumed risk was relatively low, while systemic risk was rising, especially since midway through the boom. During 2007-09 housing prices declined, demand for securitised bonds evaporated, and equity markets went into freefall, as the credit crunch and financial panic took hold. Eventually agents realised their calculative models of risk were wrong and they escalated risk assessments suddenly to reflect high levels of uncertainty as confidence in markets evaporated. Increases in liquidity preference led to greater demand for money, the flight to quality, declining aggregate demand and negative GDP growth.

Problems in the US led to liquidity problems elsewhere in the global economy in close proportion to the extent that financial institutions and agents were buying US securitised bonds. Close global linkages between financial institutions in the circuit of money capital led to chains of bankruptcy in the financial institutions, especially in Iceland, the UK, Europe, and Japan; but there were also linkages with Chinese institutions and eventually a flow-on effect to oil-based economies, many other developing nations, and global growth and investment.

\section{Principle of Contradiction and Financial Crises}

This is where the principle of contradiction becomes relevant. Contradictions are opposing tendencies associated with institutional processes, which can variously be the source of movement as well as periodic instability and crises (see O'Hara 2000, 2008a,b). The notion of contradiction is crucial for comprehending various opportunity costs between forces that have varying levels of power through time. Political economy seeks to operationalize these contradictions in real world processes. Here we are interested in the contradiction between financial stability and financial freedom, or an associated one between finance and industry. In political economy, Karl Marx (1894), Thorstein Veblen (1923), Joseph Schumpeter (1911) and J.M. Keynes (1936) wrote about these contradictions, which has been added to by various neo-Marxian, post-Keynesian, and institutional political economists. Deep periodic financial crises tend to occur historically when there is (a) long wave downswing, and also (b) a large degree of financial deregulation. These two conditions help to generate deep financial crises. Long wave downswing occurs when there is, over often 30 years, a combination of (a) product cycle maturation, (b) general low industrial profit and investment, (c) low growth per capita, and (d) institutions that are not working well (see O'Hara 2006).

Historically, major financial crises have occurred when the financial system was excessively deregulated (in principle it should also occur when finance is excessively regulated). Most advanced capitalist economies deregulated in the 1970s and 1980s, leading to the instabilities of the 1980s, 1990s and 2000s. Most Asian economies deregulated their financial systems in the 1980s and early 1990s, leading to many of the instabilities of the Asian crisis of the late 1990s. The state tended to respond to these crises by re-regulating to some degree, through the intervention of a proper reserve bank, prudential controls, and lender of last resort (especially in Asia). In the US the corporate crisis of the early 2000s led to the Sarbanes-Oxley Act to improve governance in 
corporations. However, especially in economies controlled by finance (eg, the US, UK), the subsequent boom leads to a distant memory of these earlier problems and further financial innovations that have been untested in history (eg, securitized subprime mortgages). This can lead to further instabilities further down the track.

In this light, Figure 2, below, provides a very simple illustration of the contradiction between finance and industry, where the striped bar represents the distribution of the economic surplus between finance and industry, and the black bars represent crisis areas where instability and deep recession set in (as the economic surplus bar moves downward in the south/ west direction).

Figure 2. Contradiction between Finance and Industry

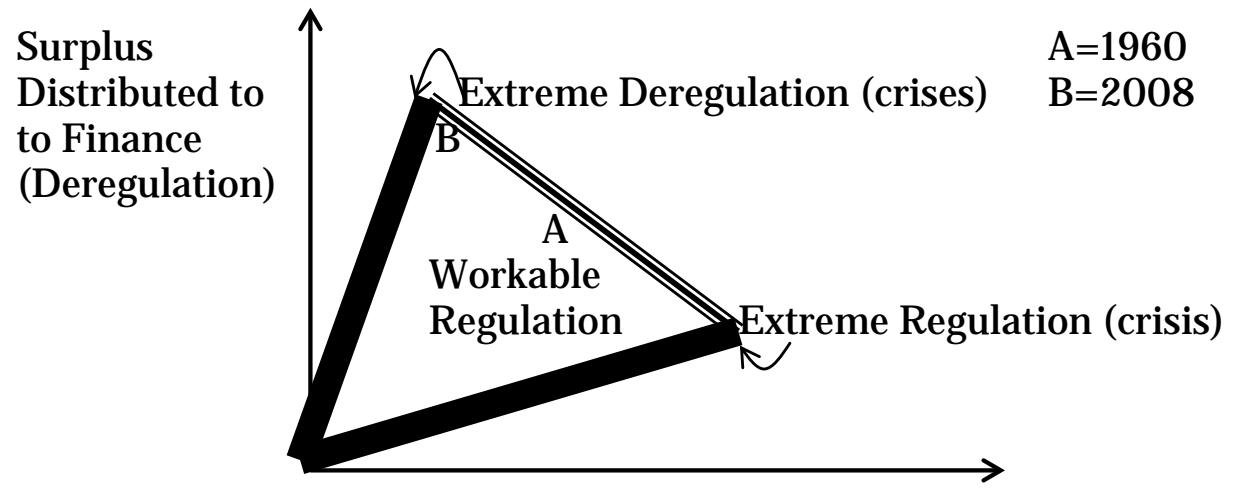

\section{Surplus Distributed to Industry (Financial Stability)}

These are bars (rather than points) due to an element of indeterminacy arising from degrees of uncertainty, institutional ambiguity, and informational problems which inhibit exactitude. Finance is defined relative to the surplus being distributed to financial institutions dealing in financial instruments, securities and advice. Industry is defined as investment in manufacturing, high-technology, and research and development. Contradictions relate to opportunity costs. For instance, for a workable long-term relationship there needs to be a relative balance between industry and finance, such as in area "A", during the 1950s, 1960s through to the early 1970s (in most economies except sub-Saharan Africa) when finance tended to be directed to the interests of industry. However, long wave downswing from the mid-1970s led to waves of financial deregulation through the following three decades in many nations. This led to the general movement towards the black bar area of "B", where finance has been dominating industry (except in some areas where long wave upswing is in motion; eg, parts of Asia). Financial domination of industry is also the result of declining relative (and often absolute) productivity and the movement of industry from advanced capitalist economies, for instance, to Asia (especially China).

When finance dominates industry there is a misallocation of resources from industry to finance, which reduces (or reflects the declining) productive investment and leads to an emphasis on short-term market rates of return in the equity markets, the payment of fees on innovative financial instruments, and the rate of turnover rather than quality of debtors. To some degree this is merely a declining metamorphosis of previously dominant economies as the rate of return from industry declines and activities turn to 
finance as an alternative. The rise in finance (along perhaps with other services) is thus both cause and effect of declining profit for highly productive sectors. As the industrialcapitalist sector of industry becomes depleted the "household" sector takes on a life of its own through higher credit rates and consumption demand, even as real wage are relatively constant or falling.

Some of the manifestations of this trade-off between industry and finance, and the opportunity costs involved, are shown below in Table 4 for the US:

Table 4. Financial Domination of Industry, USA, 1973-2005

\begin{tabular}{|l|l|l|l|l|l|l|l|}
\hline \multicolumn{1}{|l|}{} & 1973 & 1979 & 1989 & 2000 & 2005 & $\% \Delta 1973-2005$ \\
\hline FSDebt/ DDebt & $9.7 \%$ & $11.8 \%$ & $18.7 \%$ & $30.1 \%$ & $31.5 \%$ & $\uparrow 224.74 \%$ \\
\hline Mortgage Debt/GDP & $48.7 \%$ & $51.9 \%$ & $65.5 \%$ & $74.0 \%$ & $97.5 \%$ & $\uparrow 100.21 \%$ \\
\hline FA/TA for NFE & $36 \%$ & $40 \%$ & $54 \%$ & $94 \%$ & $108 \% *$ & $\uparrow 200.00 \%$ \\
\hline
\end{tabular}

Source: Adapted from Palley (2007: various pages); Orhangazi (2008:866); *=2003

These developments in the USA are fairly typical of developments in other advanced neoliberal economies, such as the UK and France (see Stockhammer 2004, Binswanger 2004). For the US, financial sector (FS) debt as a proportion of total debt increased by over 200 percent from the mid-1970s to the mid-2000s. Mortgage debt for households increased relative to GDP by over $100 \%$ during this period. And financial assets as a proportion of tangible assets for non-financial corporations rose by $200 \%$. One reason that finance was able to grow faster than industry in mature capitalist economies, in particular, is that speculative bubbles (and fees) can enhance the grouth of finance if they crash/decline back to fundamental values, rather than below fundamentals. Likely this is what happened in the mid-1970s, early 1980s, late 1980s and early 1990s, and again in the early 2000s. However, if they crash below fundamentals (albeit a slippery concept), as is likely in the current crisis, this will likely upset the dynamics of financial dominance, and propel re-regulation of the financial system. Indeed re-regulation and post-neoliberal practices are expanding around the world, which possibly may eventually generate a successful new financial social structure of accumulation for some nations (see O'Hara 2002).

Financial deregulation and innovation thus expand the rate of credit, during business cycle upswings, to often dangerous levels, which result in crises. More latterly in the US, much of this credit came through the capital account surplus (to balance the current account deficit). But it came not just as potentially productive FDI, but more importantly also as European and Asian money buying securitised mortgage-backed securities (MBS), ie, bonds; a form of endogenous credit. In this way US debt escalated while Europe (especially) and Asia (quite a bit) came to hold many of the problem bonds. Thus the GSSMC was typically one of these periods of dangerous overexpansion of lending and credit to risky customers. Here the bubble was especially important for the housing and stock markets, eventually leading to the crash in the US, and through regional and global linkages affecting other areas of the globe.

There was much variability throughout the US, with housing prices declining (Aug 2007-Aug 2008) by 18.0 percent in the "West", 9.3 percent in the "South", 3.9 percent in the "Northeast", and 2.3 percent in the "Mid-west" (Integrated Asset Services 2008). An international study showed that for the first time in the past 100 years the housing bubble has become closely synchronised, at least vis-à-vis the four nations studied. The housing bubble was shown to be (as of March 2006) in the order of 20 percent above fundamentals 
in the US, 56 percent in the UK, 67 percent in the Netherlands, and 35 percent in Norway. (Soerensen 2006). The multiple bubble crashes of 2007-2009 have moved prices closer to fundamentals, probably eventually below fundamentals. This has instigated major uncertainty around the globe, generating the biggest financial and economic crisis since the Great Depression of the 1930s.

\section{Principles of Financial Innovation and Heterogeneous Agents}

The principle of financial innovation is especially important. Where innovations, usually during short cycle upswings, generate more power to finance, major crises often eventually emerge. Consider disintermediation and securitisation of the sub-prime mortgage markets. These innovations enhanced the power of finance. Financial innovations along with cyberindustrial innovations (eg, the internet) are important for the long-term reproduction of economic growth and development. Initially, however, these innovations can exacerbate instabilities since they are new and noone can be certain about their impact on the economy because of lack of experience in their workings and also lack of knowledge about the changes wrought through their power and motion.

The principle of heterogeneous agents in political economy argues that operators in the economy are not homogenous, but rather act through different social roles. The major types of roles include different class and non-class processes associated with workers and capitalists, industrialists and financiers, buyers and sellers, men and women, and different ethnic groups. Also important are a number of micro-roles in the securitized subprime circuit (as part of the wider circuit of money capital), shown in Figure 3, below:

Figure 3. Circuit of Securitizised Subprime Financing, Heterogeneous Agents
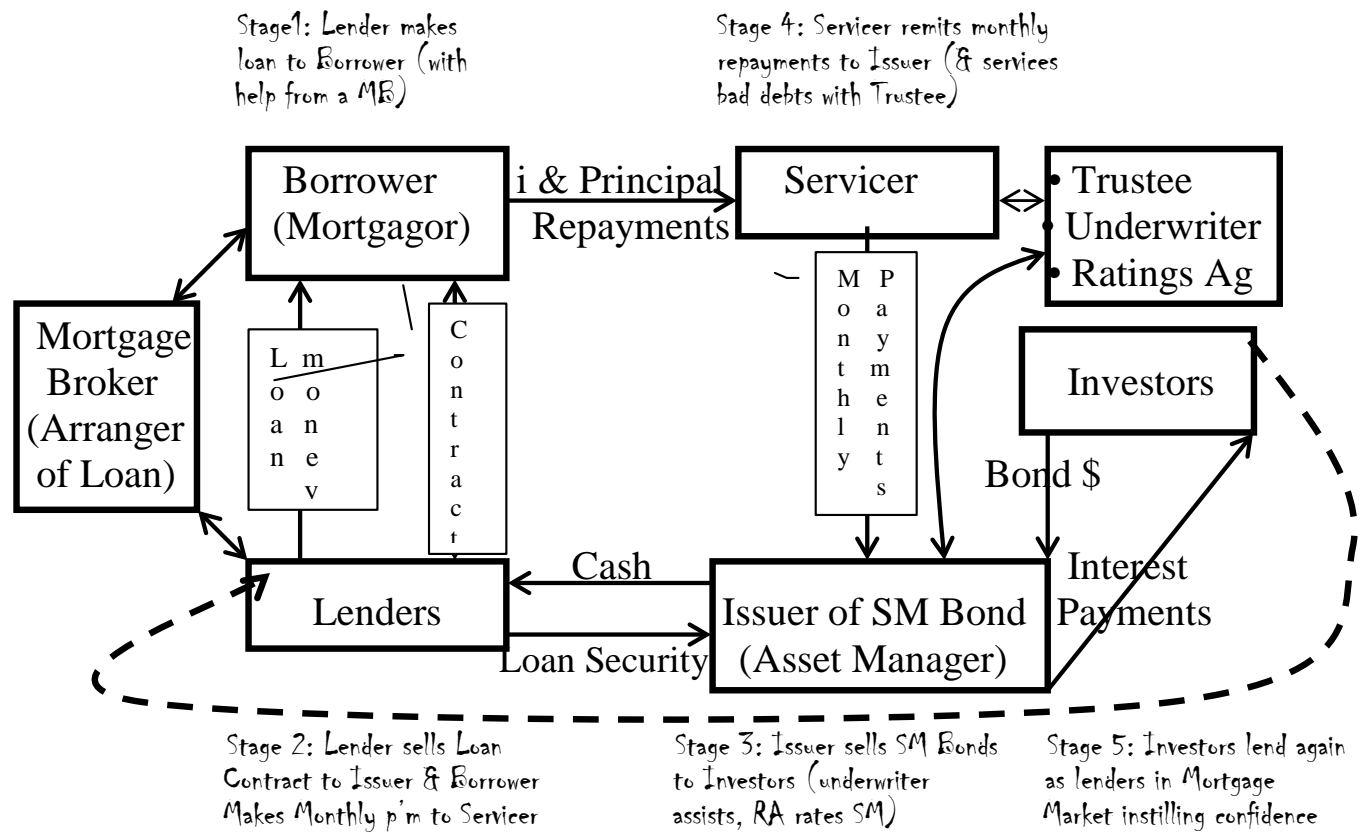

Source: Adapted from Wikipedia (2008), Ashcraft \& Schuermann (2007) 
Stage one in the circuit is when mortgage loan arrangers (brokers) bring a multitude of borrowers and lenders together for contractual commitments relating to mortgages. The second stage is where many mortgage lenders sell loan arrangements to issuers of securitised bonds; while borrowers make monthly repayments to servicers. The third stage is when issuers of securitised bonds, made up of a multitude of hundreds or thousands of different mortgages, sell securitised mortgage bonds to investors (underwriters may assist and rating agencies [RA] rate the bonds). The fourth stage is when servicers remit monthly repayments to the issuers of the bond (and service bad debts with the trustee), who in turn pass a percentage of the funds onto investors. The fifth stage of the circuit is where degrees of confidence held by "investors" generate varying degrees of action by the arranger to continue such practices on an ongoing basis. This circuit undergoes successive rounds of action, usually of a cumulative nature due to the dynamics and contradictions embedded in the institutional relationships between the heterogenous agents.

Securitization for mortgage debt is thus where different classes of mortgages are bundled together and sold as a package through a chain of agents and institutions, resulting in the formation of a mortgage bond. In this package are prime and subprime mortgages. Originally these bonds were sold as investment grade securities, thanks to the rating agencies, even though through the mid-late 2000s subprime components represented an increasing proportion of the total. Securitized mortgages as a percentage of total mortgages rose from $0 \%$ (1965) to $5.3 \%$ (1975) to $22.5 \%$ (1985) to $50.0 \%$ (1995) to 56.5\% (2005) (Schnure 2005:23).

There are four classes of mortgage loans: Agency, J umbo, Alt-A, and Subprime. Agency loans relate to prime borrowers conforming to government underwriting standards. J umbo loans include prime borrowers with a principal balance larger than government standards. Alt-A loans relate to borrowers not conforming to government limits due to high leverage or lack of documentation for income. Subprime loans link to borrowers with a lower-thanprime credit rating. The recent subprime crisis has been linked to both subprime and Alt-A loans, which collectively rose from 7.42 percent (2001) to 42.02 percent (2006) of total issuance of mortgage loans (Ashcraft and Schuermann 2008:7).

In most nations, the main debtors in the subprime market have been minority ethnic groups. For instance, during 2005 in Washington DC, African-American borrowers represented $70 \%$ of subprime home borrowers, followed by Latino borrowers at $9 \%$; while in New York during 2006, 41\% were African-American, 29\% Hispanic, and 14\% Asian. In New York, the ten worst-hit neighbourhoods were from "poor" (mostly "ethnic") communities. (Sassan 2008.) Generating financial innovations that depend on rising (often relatively unsecured) debt among the poorest sections of the community is a recipe for disaster, especially when the "honeymoon interest rates" typically disappear after a couple of years, during which interest payments tend to double. The best way to stimulate house-ownership among the poor is to encourage the building of durable skills and jobs that stimulate sustainable income flows (Fernandez et al 2008).

The development of these new financial relationships between economic agents created difficulties of an informational and social capital variety. During the 1950s to 1970s, housing finance linkages were based on trust, direct interaction and the copious gathering of information. Finance was instituted to look after the collective action problems of providing finance for business and households. Deregulation stimulated anonymity between parties, market pricing rather than historical costing, and the pricing of risk based on dubious calculative norms. For instance, deregulation stimulated a marked shift in the relationship between borrowers and lenders. The previous borrower-lender style was broken in favour of more distant relationships between agents. 
During long wave upswing (1950s to early-1970s), the old style generated substantial home-ownership among working people, since growth and income were expanding considerably. The new style (1990s-2000s) is based on increasing the velocity of lending to subprime mortgagees, along with rapidly growing securitisation of MBS, while at the same time unwittingly generating a system-crisis of uncertainty which led to foreclosures for more than 3 million poor mortgagees in the US alone. This was associated with a decline in both bonding (within groups) and bridging (between groups) social capital. As Raymond Brescia (2008) found, the new financial instruments seemed to be based on encouraging low income households to acquire property while also doing exactly the opposite (a classic contradiction). Poor mortgagees were encouraged to take on mortgages while paying excessive interest rates (after a couple of years), having difficulty renegotiating terms when foreclosure was likely, being worse off than if they never purchased a home (in losing whatever deposit - and dignity - they might have had), and having little information about alternative arrangements that could have been made with other institutions.

This decline in social capital led to worse communication between lenders and borrowers, inadequate information flows, lack of contract flexibility, higher risk-taking, dubious ethical standards of financial intermediation, and as a result high levels of systemic uncertainty. The complexity of the relationship between agents and institutions involved in mortgage backed securities, collateralized debt obligations (CDOs), and credit default swaps led to a whole range of other factors enhancing risk and uncertainty.

\section{Risk and Uncertainty}

Issues of risk and uncertainty are critical to the GSSMC. The work of Frank Knight (1921), J .M. Keynes (1936), and G.L.S. Shackle (1955) has laid the ground-rules of this analysis, and many other political economists have taken the analysis further. Risk is where the financial aspects are said to be calculable and fairly determinate, such as the throwing of a dice, or the chance of being in an automobile accident. But uncertainty is where there is relative ignorance, or concerns the distant future of which knowledge is lacking or ambiguous. One can place risk and uncertainty on a continuum, as shown below in Figure 4 , with risk at one end and uncertainty at the other, with elements of both in the middle:

\section{Figure 4. Risk and Uncertainty Continuum}

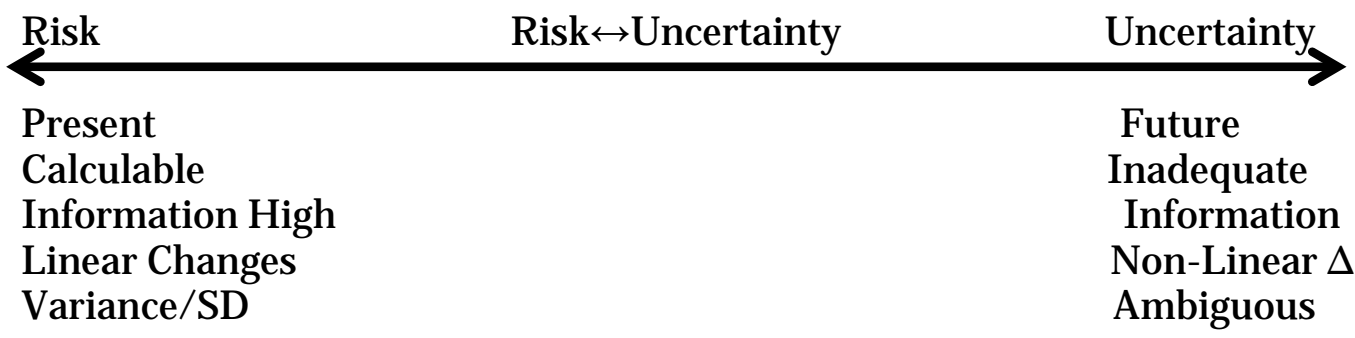

Source: Adapted from Garnaut (2008:8)

The main contradiction of capitalism, according to Keynes (1937), is that it is based on deep, durable capital structures, concerning future yields, which require both internal funding and, in addition, extensive credit in the present, based on an outcome that is radically uncertainty. These uncertainties have an element of nonlinearity, hysteresis and irreversibility as feedback processes change parameters, thereby producing circular and cumulative impacts. Apparently small changes can have large impacts, although the cycles 
tend to be endogenous both in the upswing and downswing, while complications lead to uncertainty taking hold, whereupon deep recession or depression are likely. In the current context, there is a major contradiction between the calculative models of risk employed by firms and ratings agencies in the securitised subprime industry (and elsewhere) and the emerging systemic risks that are the result of endogenously rising uncertainty.

The Basal Accord (Mark II) incorporated specific risk assessment models into the equation, due to persuasive corporate risk assessors who had "learnt the lesson" of the Savings and Loan crisis of the 1980s, and the limits of Basel I. While Basel II applied primarily to international banks, and has only recently come into play, some of the techniques have become more widely used. Calculative, risk-based pricing models are one of these techniques that came into general normative practice, especially into the 1990s and 2000s, specifically linking to the presumed ability of clients to repay their debt. The idea behind these calculative models is that if interest rates paid are closely linked to the specific risk of clients then expansion could proceed logically and rationally. The normative convention or "enabling myth" (Dugger 1996:29-33) of so-called "scientific assessment of risk" thus emerged so that economic action could be justified as a result of technical analysis of the factors involved. It thus appeared that, for instance, people with a poor credit history could be included in the market if their risks were adequately priced and lenders compensated accordingly. Scores based on these models and methods, such as FICO scores, tend to adopt this philosophy of compensating institutions for greater risk by charging higher rates.

It is well known that these calculative models tend to assume risk moves in an anticyclical fashion (with a lag) because the risk weightings are based on expectations about the future determined by the prevailing business climate (Balini 2008:15). Hence "recognised risk" (rather than actual risk) will tend to rise immediately before the cycle reaches its upper turning point and (especially) into recession, and decline just before the lower turning point and into recovery through to high-boom. The models also do not consider the desirability of high risk individuals with unsecured debt not being extended loans due to a threshold expansion of risk in the face of unlikely but possible scenarios. They also assumed erroneously that bundling higher risk subprime together with lower risk mortgages into a bond would cancel out much of the risk of the subprime element, even as the proportion of subprime in the bond increased (Mizen 2008: 554). Stress testing by the use of alternative assessments based on changes in various markets and environments was not standard practice.

In general, risk assessments made by financial institutions, including Moody's, Standard and Poor's and Fitch, did not incorporate systemic risk into the equation. In attempting to calculate the risk of individual borrowers, broader questions of interdependencies, the complexity of the securities and systemic linkages were abstracted from. Business cycle upswing was assumed to generate low risk, with risk likely rising only immediately before and during recession. This core problem is quite apart from the fact that many of the individual risk assessments were done with an emphasis on speed of acceptance, and with little regard for rigorous information gathering and analysis.

The calculative risk assessment models did not adequately consider uncertainty that may (suddenly) rise in the future; even in broad terms of including different scenarios in the assessments. In being deterministic they exaggerated the degree of certainty about their assessments and ignored the systemic sources of risk at the macro or global level that emerge due to interdependencies between agents, markets and institutions. There was no attempt to use what Martin Hellwig (2008:21) calls a 'holistic approach' to risk and uncertainty, combining specific data with a broader understanding of cycles and tendencies of the macro and global economies. 
These problems could have been alleviated by building on the work of Michal Kalecki and Hyman Minsky (see O'Hara 2001). This tradition recognised that risk and uncertainty tend to be procyclical (with some lags); with cycle upswings (especially during long wave downswings) eventually leading to much higher and sudden increases in risk when instability reaches a tipping point (threshold effect). This principle of increasing risk, considered broadly, is important for recognising the endogenous systemic risks and uncertainties that tend to rise during a boom. The Kalecki-Minsky tradition helps comprehend the subprime experience of massive credit downgrades, bankruptcy, liquidity crisis and recession during 2007-09 (but is ignored in the calculative models of risk). This tradition especially helps to comprehend the following problems in the GSSMC:

The Emphasis on Velocity rather than Quality. There was a disproportionate emphasis on the velocity of growth of securitized subprime mortgages (assuming property prices would keep growing), rather than the quality of the mortgages in the securities (bonds). The importance of velocity became a normative standard of judgement embedded in the collective consciousness of the players in the markets (quality was assumed to be reflected in mechanical calculative risk assessment models). (Sassen 2008:204.) Eventually "recognised risk" rose during 2008 to (broadly) equate with "actual risk", after a longlag.

Evolution from Conservative to Market Accounting. There has been a switch from historical cost (conservative) to fair market value accounting and shareholder value over recent decades. This generates a "discrepancy" between the "financial investment" horizons of agents (daily or weekly) and the long-life of real estate houses and buildings (several decades). This led eventually to bubbles crashing below fundamentals, as "market pricing" led many financial institutions into both illiquidity (a common problem in a credit crunch) and insolvency (common during recession), since in the face of a liquidity crunch and panic they immediately had their assets devalued according to "market prices". (Hellwig 2008:7). However, during the credit crunch and especially financial panic it became difficult to ascertain what "fair values" are due to information problems and uncertainty.

Increasing Distance between Underlying Assets and Instruments: Financial dependence and dominance led to innovations, based on profit-making schemes that expand the distance between underlying assets (mortgages) and financial instruments (securitised mortgages). This "originate-and-distribute model" generated a major contradiction with securitization, namely that "outsourcing the funding side of an originator's balance sheet undermines its incentives to monitor the quality of the loans it originates" and as a result "troubled loans become the property and problems of someone further down the transaction chain" (Caprio et al 2008:12). There were informational frictions between borrower and mortgage broker; originator and arranger; arranger and third parties; servicer and borrower; servicer and third parties; asset manager and investor; and investor and credit-rating agencies (see Ashcroft and Schuermann 2007:2-3).

Calculative Risk Models ignored Systemic Risk and Uncertainty. The mechanical calculative models of risk were unable to include 'systemic uncertainty' into the analysis. The risk-based pricing models were legitimised through "rigorous" credit-scores and letterrelated risk for MBS, along with the use of credit-default swaps which led many borrowers to be indifferent to (or even encourage) default on the part of debtors. There was to this point only a limited history of mortgage securitization, which made it difficult to ascertain the future impact of their rapid expansion. Moody's, S\&P and Fitch concentrated on the rising market rather than potential future decline in real estate prices, rising interest rates, rising default rates, and recession (or different scenarios). (Langley 2008:477-85). 
Use of Structured Investment Vehicles (SIVs). SIVs issue short-term commercial paper (liabilities) to fund longer-term assets such as CDOs. In order to evade Basel guidelines, many banks organised SIVs to deal with these assets and liabilities, to prevent them from being shown on their balance sheet, which reduced the (low risk) capital requirements of banks. The assumption was that SIVs could engage in these activities without it affecting the viability of the banks themselves. When problems emerged in these vehicles many banks, such as Northern Rock and Bank of America, saw the need to include SIV positions on their balance sheet, which affected bank profit and net worth position, often leading to liquidity problems and insolvency.

Credit Default Swaps (CDSs). One factor increasing systemic uncertainty was the use and abuse of CDSs. A buyer purchases a CDS from a seller for use as hedging against a loss in their (mortgage-backed) securities, or as speculation that other companies will experience a loss, or for arbitrage purposes. During late 2007 the private market in CDS had reached US $\$ 45$ trillion, 45 percent for speculative purposes. Illiquidity and insolvency problems for AIG and Lehman Brothers, in particular, generated panic in the CDS market (and the wider national and global economies) during late 2008 as these companies had a large stake in CDSs. Trillions of dollars worth of CDSs became worthless as Lehman Brothers became insolvent. Systemic risk suddenly increased as thousands of firms were exposed to losses.

Securitized Mortgage Bonds Infected Global Circuits of Finance. Through national, regional and global networks the pro-cyclical innovations such as subprime mortgage bonds, collateralized debt obligations and credit default swaps with high system-risk infected not only national but also global markets. As they entered the financial circuits their growing velocity gradually built up a massive system-risk that mechanical calculative models failed to recognise. System-problems became blatantly obvious from late-2007 (Sassen 2008:208), and became worse in late 2008. The inability of calculative models of risk and deterministic worldviews to quickly "solve" the contradiction between individual risk and systemic uncertainty helped to initiate a breakdown of the financial and economic system (a credit crunch, financial panic and recession) in economies directly and indirectly linked to the circuit of securitized subprime financing.

\section{Conclusion}

The purpose of this paper has been to scrutinise the global securitised subprime market crisis through the lens of some of the core general principles of political economy. We sought to tell a useful and interesting story about the origins and trajectory of the crisis, drawing on the conceptual edifice of political economy. Through this method the historical underpinnings of the crisis have been briefly introduced. The multiple factors cumulatively affecting the circuit of money capital have been interactively described. The contradictory processes affecting the relationship between finance and industry have been analytically explored through the deregulation experience and changing global patterns of industrial production. The importance of financial innovation and heterogeneous agents has highlighted the way in which complexities and changing relationships between people have increased uncertainty and instability. And finally the conventional use of calculative models of risk to encourage further credit, housing activity and equity expansion in the face of greater levels of systemic uncertainty illustrate the process of endogenous crisis and deep recession. The next stage is to examine the crisis in relation to policy and governance (see O'Hara forthcoming).

\section{References}


Ashcraft, Adam B. and Til Schuermann. 2007. Understanding the securitization of subprime mortgage credit. Federal Reserve Bank of New York. Social Science Research Network. December. 81pp.

Baylin, Brian. (2008) Basil I, Basel II and emerging markets: A nontechnical analysis. Working Paper. Washington DC: John Hopkins University School of Advanced International Studies.

Binswanger, Matias. 2004. Stock returns and real Activity in the G-7 countries: Did the relationship change in the early 1980s? Quarterly Review of Economics and Finance 44: S. 237-252.

Brescia, Raymond H. 2008. Capital in chaos: The subprime mortgage crisis and the social capital response. Cleveland State Law Review 56: 271-318.

Caprio, Gerard J r.; Ash Demirguc-Kunt and Edward J . Kane. 2008. The 2007 meltdown in structured securitization: Searching for lessons, not scapegoats. Washington DC; World Bank. October. Policy Research Working Paper No 4756.

Dugger, William M. 1996. Four modes of inequality. In Inequality: Radical Institutionalist Vies on Race, Gender, Class and Nation, edited by W.M. Dugger. Westport, Connnecticut: Greenwood Press.

Fernandez, Luisa; Fadhel Kaboub and Zdravka Todarova. 2008. On democratising financial turmoil: A Minskian analysis of the subprime crisis. Working Paper 548. Levy Economics Institute of Bard College. November.

Garnaut, Ross. 2008. The Garnaut climate change review: Final report. 30 September. Cambridge, UK; NY. Cambridge University Press. (Available on the Internet.)

Hellwig, Martin. 2008. Systemic risk in the financial sector: An analysis of the subprimemortgage financial crisis. Bonn: Max Planck Institute for Research on Collective Goods. Research paper 2008/43.

IMF. 2008. Iceland gets help to recover from historic crisis. IMF Survey Online. 2 December.

Integrated Asset Services. 2008. IAS360 house price index. Denver, CO: IAS. Available on the Internet.

Keynes, John Maynard. 1936. The general theory of employment, interest and money. London: Macmillan, 1973.

Keynes, John Maynard. 1937. The general theory of employment. Quarterly J ournal of Economics 51: 209-223.

Knight, Frank. 1921. Risk, uncertainty and profit. New York: Cosimo Classics, 2005

Langley, Paul. 2008. Sub-prime mortgage lending: A cultural economy. Economy and Society 37: 469-494.

Marx, Karl. 1894. Capital, volume 3: The process of capitalist production as a whole. Harmondsworth: Penguin, 1981.

Mian, Atif and Amir Sufi. (2008) The consequences of mortgage credit expansion: Evidence from the 2007 mortgage default crisis. University of Chicago Graduate School of Business. Available from the SSRN on the internet.

Mizen, Paul. 2008. The credit crunch of 2007-2008: A discussion of the background, market reaction, and policy responses. Federal Reserve Bank of St. Louis Review 90: 531-567.

O’Hara, Phillip Anthony. 2000. Marx, Veblen and contemporary institutional political economy: Principles and unstable dynamics of capitalism. Cheltenham, UK \& Northampton, US: Edward Elgar.

O’Hara, Phillip Anthony. 2001. Encyclopedia of political economy. 2 Volumes. New York \& London: Routledge. (See Numerous Articles on Kalecki and Minsky.) 
O’Hara, Phillip Anthony. 2002. A new financial social structure of accumulation for long wave upswing in the United States? Review of Radical Political Economics 10: 342-348.

O'Hara, Phillip Anthony. 2006. Growth and development in the global political economy: Social structures of accumulation and modes of regulation. London and New York: Routledge.

O'Hara, Phillip Anthony. 2007a. Principles of institutional-evolutionary political economy-Converging themes from the schools of heterodoxy. Journal of Economic Issues 41: 1-42.

O'Hara, Phillip Anthony. 2007b. Heterodox political economy specialization and interconnection-Concepts of contradiction, heterogeneous agents, uneven development. Intervention J ournal of Economics 4: 99-120.

O'Hara, Phillip Anthony. 2008a. Principle of circular and cumulative causation: Fusing Myrdalian and Kaldorian growth and development dynamics. Journal of Economic Issues 42: 375-397.

O'Hara, Phillip Anthony. 2008b. Can the principles of heterodox political economy explain its own re-emergence and development? On the Horizon 16: 260-278.

O’Hara, Phillip Anthony. 2009. Principles of social and political economy applied to critical world problems.

O'Hara, Phillip Anthony. Forthcoming. Subprime crisis and policy, International Encyclopedia of public policy-Governance in a global age: Volume 2: economic policy, edited by Phillip Anthony O’Hara. Perth: GPERU, pp. 602-614.

Orhangazi, Ozgur. 2008. Financialisation and capital accumulation in the non-financial corporate sector: A theoretical and empirical investigation on the US economy: 19732003. Cambridge J ournal of Economics 32: 863-886.

Palley, Thomas. 2007. Financialization: What it is and why it matters. Annandale-onHudson, New York: Levy Economics Institute. Working Paper No 525.

RGE Monitor. 2009. Navigating the first global economic recession. RGE Monitor Newsletter. 14 J anuary. Online.

Sassen, Saskia. 2008. Mortgage capital and its particularities: A new frontier for global finance. J ournal of International Affairs 62: 187-212.

Schnure, Calvin. 2005. Boom-bust cycles in housing: The changing role of financial structure. IMF Working Paper No 05/200. Washington DC: IMF.

Schumpeter, Joseph A. (1911) The theory of economic development. Oxford: Oxford University Press, 1969.

Shackle, G.L.S. 1955. Uncertainty in economics and other reflections. Cambridge: Cambridge University Press.

Stockhammer, Engelbert. 2004. Financialisation and the slowdown of accumulation. Cambridge J ournal of Economics 28: 719-741.

Veblen, Thorstein. 1923. Absentee ownership and business enterprise in recent times: The case of America. New York: A.M. Kelley, 1964.

Wikipedia. 2008. SubPrime mortgage market crisis. Available online

Wikipedia. 2009. 2008-2009 Icelandic financial crisis. Available online.

Wolff, Richard. 2009. Capitalism hits the fan. DVD film. Northampton, MA: Media Education Foundation.

Wolfson, Martin H. 1996. Financial crises: Understanding the postwar U.S. experience. Second Edition. Armonke, NY: M.E. Sharpe.

Wray, L. Randall. 2007. Lessons from the subprime meltdown. Levy Economics Institute-Bard College of New York. Working Paper No 522. (December.) 
Phillip Anthony O'Hara is professor of global political economy and governance and director the global political economy research unit in the Curtin Business School, Curtin University, Australia. His most recent book is Growth and Development in the Global Political Economy: Social Structures of Accumulation and Modes of Regulation (2006, Routledge), and forthcoming are the International Encyclopedia of Public Policy (4 vols, $1.4 \mathrm{~m}$ words, 2009) and Principles of Social and Political Economy Applied to Critical World Problems (2009). 